\author{
Łukasz Wróblewski \\ Akademia WSB, Wydział Zamiejscowy w Cieszynie \\ (D) https://orcid.org/0000-0002-4465-0107
}

\title{
Płaszczyzny i charakter współpracy podmiotów Śląska Cieszyńskiego w procesie kreowania produktów kulturalnych na transgranicznym rynku
}

\begin{abstract}
Wróblewski's article is theoretical-empirical in character. In the first part, he focuses on a relatively recent and as yet underresearched category, that of the cross-border market. From the existing definitions of the market, Wróblewski derives a definition of the cross-border market of cultural services. He goes on to discuss the historical conditions of the creation of this market in the Cieszyn Silesia-Těšín Slezsko area. Next, he discusses the structure and specificity of the cross-border cultural product (CBCP). In the third part of the article, Wróblewski examines in detail the levels and nature of cooperation in the process of creating $\mathrm{CBCP}$ on the cross-border market of Cieszyn Silesia. He points out that local, regional, and Euroregional organizations and central authorities of the countries sharing the border are involved in the process of creating cultural products on the cross-border market.
\end{abstract}

Key words: Euroregion, culture, cross-border product, cross-border market, relations, Cieszyn Silesia

\section{Wprowadzenie}

Z początkiem lat 90. XX wieku na Śląsku Cieszyńskim zauważyć możemy intensyfikację różnego rodzaju działań współfinansowanych często ze środków Unii Europejskiej, mających na celu pobudzenie transgranicznej współpracy kulturalnej. Służą one m.in. zacieraniu granic i podziałów między państwami 
przygranicznymi. Doprowadziło to m.in. do wzrostu podaży na rynku usług kultury pogranicza polsko-czeskiego czy zmiany w zachowaniach polskich oraz czeskich odbiorców oferty kulturalnej i w konsekwencji wyodrębnienia się wspólnego transgranicznego rynku usług kultury Śląska Cieszyńskiego. Rynku bardzo specyficznego (chociażby ze względu na ciągle istniejące polsko-czeskie animozje i podziały) i jak dotąd bardzo słabo rozpoznanego oraz opisanego. Rynku, na którym obserwować możemy wzrost liczby różnego rodzaju wydarzeń realizowanych przez podmioty kultury Śląska Cieszyńskiego, bardzo często w ramach projektów, których głównym założeniem jest transgraniczność przejawiająca się m.in. w tym, że przygotowanie i realizacja wydarzenia musi przebiegać w partnerstwie polsko-czeskim, a odbiorcą usług podmiotów kultury powinien być nie tylko obywatel rodzimego kraju, lecz także mieszkaniec kraju sąsiedniego.

$\mathrm{Z}$ dotychczasowych badań prowadzonych przez autora wynika jednak, że rosnąca liczba projektów artystycznych nie przekłada się w znaczący sposób na tzw. mieszanie się polskiej i czeskiej publiczności'. Wymusza to tym samym na menedżerach podmiotów kultury pogranicza polsko-czeskiego potrzebę stałego doskonalenia struktur, komunikacji, procedur czy podejmowanych działań marketingowych. Działań, które skoncentrowane są na kreowaniu transgranicznych produktów kulturalnych (TPK) stanowiących wartość dla odbiorców oferty kulturalnej zlokalizowanych po dwóch stronach granicy. Wymaga to jednak wnikliwego, uważnego spojrzenia zarówno na różne płaszczyzny, jak i charakter współpracy podmiotów Śląska Cieszyńskiego w procesie kreowania produktów kulturalnych na transgranicznym rynku.

\section{Pojęcie oraz historyczne uwarunkowania powstania transgranicznego rynku usług kultury na Śląsku Cieszyńskim}

Dokonując opisu transgranicznego rynku usług kultury i dalej transgranicznych jej produktów, niezbędne jest określenie pojęcia kultury. Kiedy porównujemy bowiem ze sobą sposób użycia słowa kultura - charakterystyczny dla pracowników jej instytucji — z tym pojmowaniem kultury, które kształtuje się w ramach dociekań takich dyscyplin akademickich, jak filozofia, socjologia kultury czy antropologia kulturowa (etnologia), zauważamy istotną różnicę. W przypadku pierwszym - w urzędowej nomenklaturze kulturą nazywa się po prostu sposoby i środki upowszechniania kultury, inaczej formy upowszechniania kultury (działalności kulturalnej). Jerzy Kmita mówi w takim przypadku o praktyczno-administracyj-

${ }^{1}$ Więcej na ten temat w: Wróblewski, 2018; Wróblewski, Dziadzia, Dacko-Pikiewicz, 2018; Wróblewski, Kasperek, 2019. 
nym rozumieniu kultury. Wedle tego ujęcia kulturę stanowi „ogół określonego rodzaju przedsięwzięć: wieczorów autorskich, wycieczek krajoznawczych połączonych ewentualnie ze zwiedzaniem muzeów czy zabytków architektonicznych, konkursów czytelniczych, festiwali folklorystycznych, działalność różnego typu zespołów amatorskich: śpiewaczych, tanecznych, teatralnych itd." (Kmita, 1982, s. 5-6). W takim rozumieniu kultura staje się tożsama z życiem kulturalnym, czyli zbiorowym uczestnictwem w publicznych formach upowszechniania kultury. W przypadku drugim trudno mówić o jakimś jednym pojęciu, istnieje mnóstwo różnych teoretyczno-akademickich koncepcji kultury; przy całym jednak ich zróżnicowaniu nigdy nie odnosi się takiego czy innego, teoretyczno-akademickiego pojęcia kultury do tego bloku imprez i działań zespołowych, który nazywa się kulturą w ujęciu praktyczno-administracyjnym. Dla potrzeb niniejszego artykułu posłużono się terminem kultura $\mathrm{w}$ jego praktyczno-administracyjnym rozumieniu, utożsamiającym kulturę z formami upowszechniania uczestnictwa w niej i organizującymi to uczestnictwo instytucjami kultury ${ }^{2}$. Dodatkowo należy zaznaczyć, iż poruszać się będziemy w sferze kultury symbolicznej, najczęściej zaś analizowaną w pracy dziedziną kultury będzie sztuka, czyli forma świadomości społecznej regulująca praktykę artystyczną. Przez podmioty kultury w artykule rozumieć będziemy przede wszystkim publiczne, prywatne i mieszane instytucje kultury oraz firmy, organizacje nastawione na wytwarzanie różnych dóbr i usług kultury, których produkcja opiera się na przemysłowym powielaniu oryginalnych dzieł twórców3.

Przystępując do definiowania transgranicznego rynku usług kultury na Śląsku Cieszyńskim, warto posłużyć się zarówno ekonomiczną, jak i geograficzną definicją rynku. W rezultacie transgraniczny rynek usług kultury określać należy jako ogół stosunków wymiany, zachodzących między podmiotami oferującymi usługi zaspokajające potrzeby w zakresie kultury a odbiorcami nabywającymi te usługi na obszarach przygranicznych regionów państw dzielących wspólną granicę. Geograficzne rozumienie transgranicznego rynku odnosi się do terytorium, które położone jest po obu stronach granicy polsko-czeskiej, jako wyodrębniony obszar o zbliżonych warunkach dokonywania zakupu i sprzedaży. Warto w tym miejscu zwrócić uwagę na pewien problem natury definicyjnej. Otóż dość często obszar transgraniczny utożsamiany jest z obszarem euroregionu, podobnie jak pojęcie współpracy transgranicznej utożsamiane jest ze współpracą euroregionalną, co stanowi pewne uproszczenie. W tym kontekście należy zatem zastanowić się, jak powinno definiować się obszar polsko-czeskiego transgranicznego rynku usług kultury Śląska Cieszyńskiego. Współpraca euroregionalna oznacza szczególną

${ }^{2}$ Szerszą analizę funkcji kultury artystycznej zarówno wobec jednostki, jak i społeczeństwa można znaleźć m.in. w: Kroeber, Parsons, 1958; Dobrowolski, 1966; Conrad, 1971; Kłoskowska, 1980; Pietraszko, red., 1982; Kmita, 1985; Banaszak, Kmita, 1994; Fleischer, 2002.

${ }^{3} \mathrm{~W}$ niniejszej pracy pojęcie podmiot kultury będzie używane zamiennie z pojęciem instytucja kultury. Autor ma jednak pełną świadomość, że ze względu na występujące różnice między pojęciami stanowi to pewne uproszczenie (pojęcie podmiot kultury jest m.in. pojęciem szerszym). Szczegółowy podział podmiotów kultury znaleźć można m.in. w: Wróblewski, 2016. 
formę współpracy międzynarodowej i transgranicznej, wyróżniającą się dodatkową cechą, którą jest wyższy stopień instytucjonalizacji tejże współpracy. Jak zatem należy zauważyć, współpraca transgraniczna jest pojęciem szerszym niż współpraca euroregionalna, bo wspólne struktury nie są dla jej prowadzenia konieczne. Akcentuje się element funkcjonalny, czyli przedmiot i cele. Dopiero wprowadzenie stałych, instytucjonalnych form działania, czyli podkreślenie znaczenia elementu strukturalnego, powoduje, iż mamy do czynienia ze współpracą euroregionalną (Toczyski et al., red., 1997, s. 107-108; Malendowski, Szczepaniak, 2000, s. 11). Biorąc jednak pod uwagę fakt, że główny cel kreowania transgranicznych produktów kulturalnych stanowi integracja, łączenie, jednoczenie, zespalanie polskich oraz czeskich podmiotów transgranicznego rynku (m.in. instytucje kultury, odbiorcy ich oferty), zaś obszar euroregionu jest bardzo wyraźnym przejawem integracji obszarów przygranicznych, na potrzeby niniejszego artykułu przyjęto, że polsko-czeski transgraniczny rynek usług kultury Śląska Cieszyńskiego w ujęciu geograficznym rozumiany będzie jako obszar Euroregionu Śląsk Cieszyński-Těšínské Slezsko. Tak wyznaczone terytorium (około 1730 tys. $\mathrm{km}^{2}$ ) zamieszkuje blisko 672 tys. osób, z czego po stronie polskiej mieszka około 312 tys. osób, a po czeskiej - 360 tys. osób (Kasperek, red., 2014).

Wyróżnikiem polsko-czeskiego rynku usług kultury funkcjonującego w ramach Euroregionu Śląsk Cieszyński-Těšínské Slezsko oprócz wyższego stopnia instytucjonalizacji struktur są liczne powiązania instytucji kultury z wyspecjalizowanymi krajowymi i międzynarodowymi organami koordynacji współpracy transgranicznej (Mierosławska, 1999, s. 5). Poza tym o ile współpraca transgraniczna w obszarze kultury na Śląsku Cieszyńskim pomiędzy instytucjami kultury spoza obszaru euroregionu sprowadza się często do jednego, konkretnego problemu, to współpraca między podmiotami rynku Euroregionu Śląsk Cieszyński-Těšínské Slezsko zawierana jest przeważnie z myślą o długim horyzoncie czasu oraz o różnych zagadnieniach z obszaru kultury, którymi ma się zajmować (Greta, 2000, s. 449).

Analizując kalendarium kontaktów polsko-czeskich z ostatnich stu lat (zwłaszcza tych odnoszących się do Śląska Cieszyńskiego), wskazać można na wiele bardzo ważnych wydarzeń, które miały istotny wpływ na powstanie transgranicznego rynku usług kultury, w tym również na proces kreowania TPK. Kontakty te mają swoją własną historię składającą się na cykl życia transgranicznego rynku usług kultury w regionie Śląska Cieszyńskiego. Według Romana Niestroja w cyklu tym wyróżnić można cztery następujące po sobie fazy: tworzenia się rynku, wzrostu, dojrzałości oraz schyłku (Niestrój, 1998, s. 65), które stwarzają specyficzne uwarunkowania i perspektywy rozwoju dla działających na nim polskich oraz czeskich podmiotów kultury (rys. 1). 


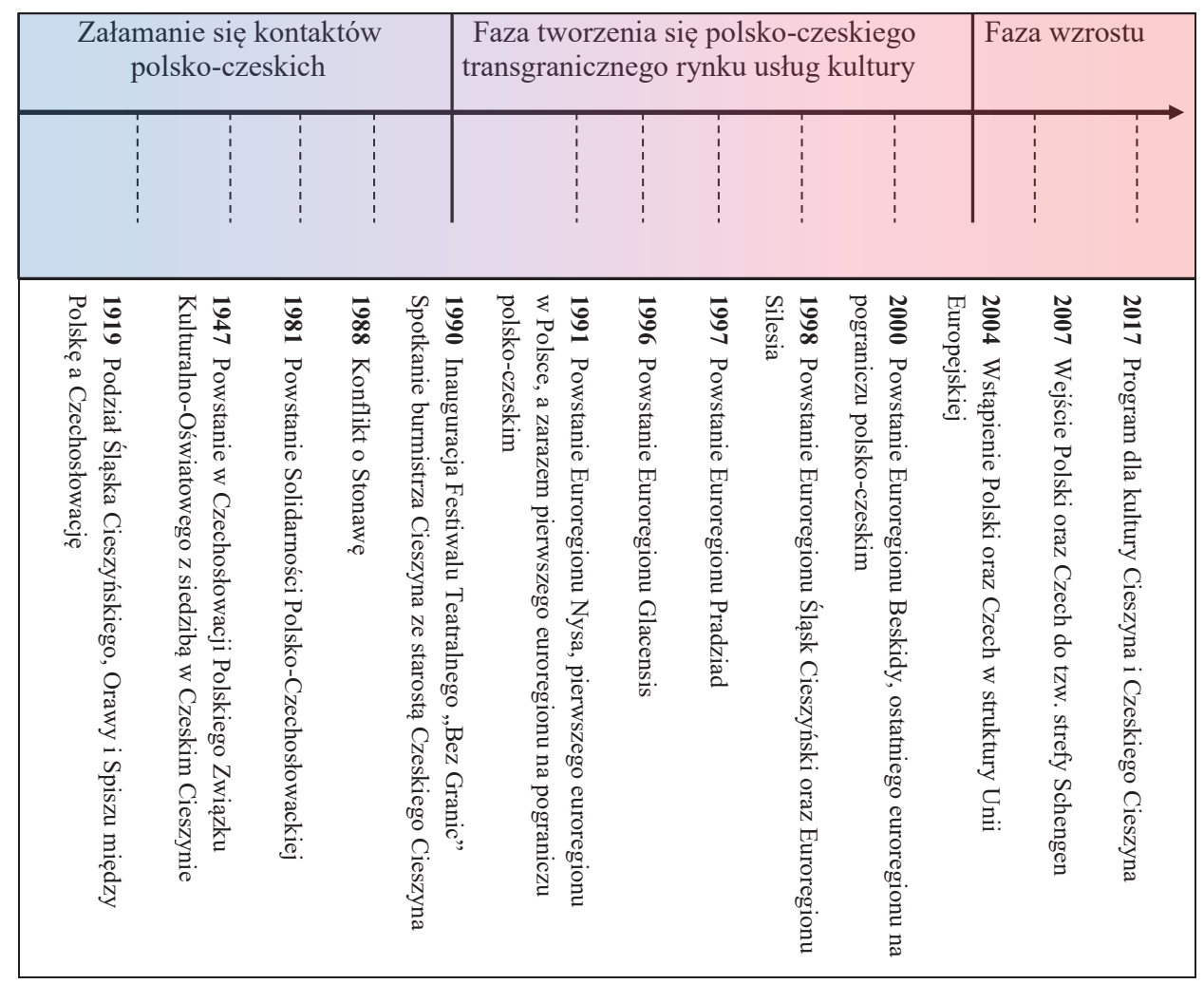

Rys. 1. „Kamienie milowe” na drodze tworzenia się i rozwoju transgranicznego rynku usług kultury w regionie Śląska Cieszyńskiego

Źródło: opracowanie własne.

Od roku 1919, kiedy terytorium Śląska Cieszyńskiego, Orawy oraz Spiszu podzielono między Polskę a Czechosłowację, zaobserwować można wyraźne załamanie kontaktów polsko-czeskich również na gruncie kultury. Występujące w tym okresie na pograniczu polsko-czeskim konflikty, interwencje zbrojne, prześladowania, wysiedlenia miejscowej ludności zarówno narodowości polskiej, jak i czeskiej na długie lata podzieliły mieszkańców Śląska Cieszyńskiego. Podziały były tak głębokie, że właściwie zablokowały systematyczną transgraniczną współpracę w obszarze kultury. Dodatkowo II wojna światowa zburzyła strukturę polskich oraz czeskich instytucji kultury, szczególnie polskich organizacji kulturalnych, które przed wojną funkcjonowały zarówno po polskiej, jak i czeskiej stronie granicy.

W odradzającym się w 1945 roku spontanicznie życiu społecznym i kulturalnym pojawiła się organizacyjna pustka, ówczesne władze czechosłowackie nie zgodziły się bowiem na reaktywowanie przedwojennych polskich stowarzyszeń i organizacji kulturalnych. Dzięki trudnym negocjacjom w 1947 roku, a także poprawie stosunków między Czechosłowacją a Polską dochodzi jednak do powstania w Czeskim Cieszynie Polskiego Związku Kulturalno-Oświatowego (PZKO) — naj-

164 większej organizacji zrzeszającej Polaków poza granicami Polski. Organizacja ta, 
prowadząca dziesiątki zespołów folklorystycznych, chórów, teatrów amatorskich, kabaretów, klubów w kilkudziesięciu Domach PZKO rozsianych na obszarze tzw. Zaolzia, pełni funkcję mostu łączącego Polaków mieszkających w Czechosłowacji (dzisiaj Republice Czeskiej) z macierzą - Rzeczpospolitą Polską. Z inicjatywy PZKO powstał również w 1951 roku jedyny polski teatr zawodowy poza granicami Polski - Scena Polska, która już od ponad 70 lat funkcjonuje w ramach Teatru Cieszyńskiego w Czeskim Cieszynie. Teatr ten ma swoich stałych odbiorców zarówno z polskiej, jak i czeskiej strony granicy.

W 1988 roku miał miejsce historyczny już spór o budowę przez władze Czechosłowacji koksowni w przygranicznej Stonawie. Ciąg zdarzeń, jaki zainicjowany został przez decyzję o uruchomieniu tej inwestycji, w tym masowość protestów lokalnych przygranicznych społeczności (zarówno polskich, jak i czeskich), był czymś wcześniej niespotykanym na polsko-czeskim pograniczu. W efekcie decyzja o budowie została zawieszona, a konflikt ten w opinii autora stał się m.in. ważnym kamieniem milowym na drodze do wyodrębnienia się transgranicznego rynku usług kultury Śląska Cieszyńskiego. Dowiódł bowiem, że nawet w tak podzielonym regionie, w którym wciąż nie zabliźniło się jeszcze wiele ran, możliwe jest przełamywanie barier, a także współpraca mieszkańców zarówno z polskiej, jak i czeskiej strony granicy. Protest ten pokazał, że możliwe jest stworzenie w przyszłości takiej atmosfery na granicy, w której sprawy wspólne dla obu społeczności, w tym również $\mathrm{w}$ obszarze kultury, będą rozwiązywane razem, z wzajemnym udziałem, a nie za plecami sąsiada (Kasperek, red., 2014).

Przyglądając się współpracy polsko-czeskiej z lat 90. na Śląsku Cieszyńskim, stwierdzić można, że właściwie główny jej ciężar spoczywał na linii Cieszyn Czeski Cieszyn. Pomimo faktu, że w innych polskich i czeskich gminach przygranicznych również notowano jakieś kontakty, to jednak nie stanowiły one przedsięwzięć programowych, obliczonych na długą perspektywę, wypracowującą trwałą płaszczyznę współpracy w ramach transgranicznego rynku usług kultury. Dzięki wprowadzeniu małego ruchu granicznego wzrosły dodatkowo powiązania interpersonalne. Rozwijała się również współpraca samorządów oraz izb gospodarczych działających na pograniczu. Paradoksalnie jednak w przypadku zarówno gmin polskich, jak i czeskich lepiej widziane było nawiązywanie partnerskich relacji z miastami z zachodniej Europy niż z najbliższymi sąsiadami zza granicy. Aktywna rola miasta Cieszyna ukierunkowana na współpracę z Czechami nie budziła przy tym zdziwienia, gdyż była oceniana jako nieuchronna konsekwencja naturalnych warunków funkcjonowania tego miasta i istnienia tam przejść granicznych (Werpachowski, 2014, s. 19).

Początków tworzenia się polsko-czeskiego transgranicznego rynku usług kultury dopatrywać się można w wydarzeniach z 1990 roku. Wtedy to z inicjatywy Solidarności Polsko-Czechosłowackiej (organizacji mającej swoje początki w roku 1981) w Cieszynie i Czeskim Cieszynie zainaugurowany został pierwszy cykliczny transgraniczny Festiwal Teatralny „Na Granicy” (obecnie Festiwal Teatralny „Bez Granic”). Jeszcze tego samego roku doszło również do historycznej wizyty burmistrza miasta Cieszyna w Czeskim Cieszynie, co zostało 
uznane za symboliczne rozpoczęcie nowego etapu we wzajemnych kontaktach (również tych w obszarze współpracy kulturalnej) między dwoma miastami. Podczas tego spotkania starosta Czeskiego Cieszyna (czeski odpowiednik burmistrza Cieszyna) wypowiedział słynne zdanie, że nadszedł czas „odwrócenia się do siebie twarzami”, co świadczyć może o charakterze wcześniejszych kontaktów — które wcześniej nie sprzyjały bynajmniej rozwojowi polsko-czeskiego transgranicznego rynku usług kultury - zarówno między tymi miastami, jak i innymi polskimi oraz czeskimi miastami rozsianymi na pograniczu polsko-czeskim. Można zatem przyjąć, że od 1990 roku współpraca w sferze kultury na polsko-czeskim pograniczu Śląska Cieszyńskiego nabiera nowego znaczenia, a mieszkańcy obszarów przygranicznych zaczęli przezwyciężać głęboko zakorzenione urazy, przełamywać narosłe przez lata uprzedzenia i historyczne zaszłości. To właśnie w sferze kultury zaczęto symbolicznie „,przekraczać granicę”, jeszcze przed wstąpieniem Polski i Czech do Unii Europejskiej, a tym samym przed zniesieniem formalnoprawnych ograniczeń w swobodnym przemieszczaniu się mieszkańców z obu państw. Przykładem takiego symbolicznego przekraczania granicy mogą być pierwsze transgraniczne wydarzenia kulturalne, takie jak: Festiwal Teatralny „Na Granicy”, Festiwal „Cieszyńska Jesień Jazzowa” czy obchodzone wspólnie przez mieszkańców Cieszyna i Czeskiego Cieszyna Święto Trzech Braci związane z legendą o założeniu miasta. W trakcie tego popularnego miejskiego święta w latach 90. przez trzy czerwcowe dni organizowane były liczne koncerty, występy czy festyny, na których wspólnie bawili się mieszkańcy Cieszyna i Czeskiego Cieszyna, i co istotne, jeden dzień świętowano przy otwartej granicy.

W latach 90. powstają na pograniczu polsko-czeskim również pierwsze euroregiony (w tym Euroregion Śląsk Cieszyński-Těšínské Slezsko), które odegrały i stale odgrywają ważną rolę w kształtowaniu się transgranicznego rynku usług kultury. Te ponadnarodowe formy współpracy sprawdzają się już przeszło pół wieku w różnych miejscach Europy, w tym również od 1991 roku w Polsce. Tym, co wyróżniało fazę tworzenia się polsko-czeskiego transgranicznego rynku usług kultury, były chęć i wola tworzenia (budowy), obok istniejących — szeroko rozumianych — mostów w obszarze kultury, również mostów zaufania, współpracy oraz współdziałania, kreowania wspólnej przyszłości. W okresie tym „ludzie kultury” działający po obu stronach polsko-czeskiej granicy budowali przede wszystkim wzajemne zaufanie, pojawiały się także nowe organizacje kultury funkcjonujące w ramach tzw. trzeciego sektora.

Wraz z powstaniem Euroregionu Śląsk Cieszyński-Těšínské Slezsko pojawiły się również nowe możliwości dotyczące finansowania podejmowanych przedsięwzięć kulturalnych, tym samym działacze kultury zaczęli przygotowywać i realizować wspólne wydarzenia kulturalne. Był to czas niewątpliwie bardzo trudny, ponieważ wspólne polsko-czeskie przedsięwzięcia bardzo często oznaczały dwa projekty, które się ,ze sobą spotykały”. Był to jednak również okres, kiedy instytucje kultury pogranicza polsko-czeskiego mogły się dobrze przygotować do 166 wejścia w drugą fazę cyklu życia transgranicznego rynku usług kultury, kiedy 
pojawiły się instrumenty rzeczywiście dające możliwość pełnej współpracy (Olbrycht, 2014, s. 11-12).

Za symboliczną datę wejścia transgranicznego rynku usług kultury Śląska Cieszyńskiego $\mathrm{w}$ fazę wzrostu przyjąć można datę 1 maja 2004 roku, kiedy to Polska oraz Czechy stały się członkami Unii Europejskiej. Chociaż, jak wspomniano wcześniej, współpraca transgraniczna w obszarze kultury z powodzeniem rozwijała się na zasadzie inicjatyw oddolnych jeszcze przed rokiem 2004, to transgraniczny rynek usług kultury Śląska Cieszyńskiego swój wzrost w dużym stopniu zawdzięcza wsparciu finansowemu otrzymanemu po wejściu Polski oraz Czech w struktury unijne. Rozszerzyły się wówczas możliwości finansowania inwestycji realizowanych w sektorze kultury na pograniczu polsko-czeskim. Dzięki funduszom unijnym zorganizowano wiele transgranicznych wydarzeń kulturalnych, zrealizowano również projekty z zakresu modernizacji obecnej i rozbudowy nowej infrastruktury kultury. Pierwsze programy unijne wspierające współpracę transgraniczną na południowej granicy Polski pojawiły się w latach 90. W latach 1995 i 1996 w programie Polska — Czechy—Niemcy na działania stymulujące kontakty społeczności pogranicza trzech państw przeznaczono co roku 1,5 mln euro. W roku 1999 powołano program polsko-czeski ze środkami początkowo na poziomie $3 \mathrm{mln}$ euro, a w latach $2000-2003-5 \mathrm{mln}$ euro. W pierwszych latach po wejściu Polski i Czech do Unii Europejskiej obowiązywał Program Inicjatywy Wspólnotowej Interreg IIIA Czechy—Polska 2004—2006. Jednym z priorytetów tego programu było wspieranie struktur wzmacniających współpracę oraz kontakty między społecznościami lokalnymi po obu stronach granicy w ramach mikroprojektów. Dofinansowywano projekty, które związane były z organizacją imprez kulturalnych i sportowych, seminariów, warsztatów, szkoleń (w tym językowych), z tworzeniem transgranicznych instytucji społecznych i gospodarczych, z wspieraniem wymiany młodzieży, z rozwojem turystyki. Po stronie polskiej przeznaczono na tego typu działania około $18 \mathrm{mln}$ euro. Program ten następnie został zastąpiony Programem Operacyjnym Współpracy Transgranicznej Republika Czeska Rzeczpospolita Polska 2007-2013 (POWT), w którym na znaczeniu zyskały działania transgraniczne. Stały się one samodzielnym celem europejskiej polityki spójności, co doprowadziło do zwiększenia środków finansowych. Na program ten przeznaczono około $219 \mathrm{mln}$ euro, podniesiono również maksymalną wysokość dofinansowania do $85 \%$. Beneficjantami tych projektów były przede wszystkim jednostki samorządu terytorialnego (w tym bardzo często samorządowe instytucje kultury), uczestniczyły w nich też szkoły i uczelnie wyższe.

Kolejne istotne z punktu widzenia rozwoju polsko-czeskiego transgranicznego rynku usług kultury dziejowe wydarzenie to wejście Polski oraz Czech do strefy Schengen dnia 21 grudnia 2007 roku. Po tym dniu de facto zniesiono formalne ograniczenia przepływu ludzi, co znacząco ułatwiło ruch lokalny, a także dało dodatkowy impuls do wzrostu transgranicznego rynku usług kultury Śląska Cieszyńskiego. Wzmocniło to dotychczasowe relacje łączące zarówno instytucje kultury, jak i mieszkańców pogranicza polsko-czeskiego. Od tego momentu na transgranicznym rynku Śląska Cieszyńskiego obserwować możemy znaczący 
wzrost liczby organizowanych wspólnych przedsięwzięć kulturalnych czy realizowanych przez instytucje kultury projektów transgranicznych. Duża ich liczba, a także poprawiająca się jakość i dynamika polsko-czeskich kontaktów transgranicznych w dziedzinie kultury wskazuje, iż rynek ten może w przyszłości jeszcze bardziej się rozwinąć, dogłębniej się zintegrować (Fundusz Mikroprojektów..., 2015, s. 51-79). Należy przy tym pamiętać, że dalszy jego wzrost wiązać się będzie z dużym nasileniem konkurencji o udział w rynku. Dodatkowo na rynku tym zwiększał się będzie udział powtórnych odbiorców oferty kulturalnej, a tym samym wzrost ich doświadczenia, wymagań i w rezultacie siły przetargowej. Sytuacja ta wymagać będzie od menedżerów polskich oraz czeskich podmiotów kultury Śląska Cieszyńskiego stałego poszerzania i doskonalenia transgranicznych produktów kulturalnych, a także jeszcze lepszego wykorzystania nowoczesnych technologii oraz nowych mediów w komunikacji marketingowej. Wymagać to będzie również adaptacji przez instytucje kultury koncepcji marketingu relacji.

Ostatnim etapem cyklu życia rynku, w tym również transgranicznego rynku usług kultury Śląska Cieszyńskiego, jest schyłek. Według Niestroja faza ta charakteryzuje się trwałą tendencją do spadku popytu, która wywołana jest $\mathrm{z}$ reguły zmianami zachodzącymi w ogólnym otoczeniu danego rynku, takimi jak:

- pojawienie się nowych technologii produkcji i sposobów zaspokajania danej potrzeby;

- kurczenie się rozmiarów rynku wywołane zmianami strukturalnymi po popytowej stronie rynku (zmiany demograficzne, koncentracja i/lub kurczenie się sektorów nabywających dany produkt itp.);

- zmiany potrzeb wywołane przyczynami socjologicznymi, kulturowymi lub stylem życia itp. (Niestrój, 1998, s. 69).

Jeszcze z początkiem 2020 roku, kiedy transgraniczny rynek usług kultury Śląska Cieszyńskiego znajdował się w fazie szybkiego wzrostu, trudno było wyobrazić sobie, by mieszkańcy pogranicza polsko-czeskiego przestali przejawiać zainteresowanie kulturą, a tym samym zgłaszać zapotrzebowanie na usługi oferowane przez jej instytucje. Sytuacja jednak radykalnie zmieniła się wraz z nadejściem pandemii koronowirusa, która doprowadziła do częściowego zamknięcia granicy polsko-czeskiej i istotnie ograniczyła funkcjonowanie polskich i czeskich podmiotów kultury na Śląsku Cieszyńskim. Należy również pamiętać, że nawet po ustąpieniu wirusa SARS-CoV-2 z różnych względów możliwy jest spadek popytu spowodowany chociażby wzrostem cen na usługi kultury. Wzrost cen może być związany m.in. z ograniczeniem w nowej perspektywie finansowej Unii Europejskiej dostępu do środków finansowych na realizację transgranicznych wydarzeń kulturalnych. Należy bowiem pamiętać, że dzięki unijnemu wsparciu finansowemu wiele usług na transgranicznym rynku oferowanych jest bezpłatnie lub po znacznie obniżonych cenach, na preferencyjnych warunkach. Nie należy również całkowicie wykluczać sytuacji ewentualnego wyjścia Polski i/lub Czech ze strefy Schengen czy struktur Unii Europejskiej, co może wiązać się z wprowadzeniem utrudnień w swobodnym

168 przemieszczaniu się mieszkańców z obu stron granicy. 


\section{Transgraniczny produkt kulturalny jako przedmiot rynkowej wymiany}

W myśl teorii marketingu produktem jest wszystko, co stanowi przedmiot rynkowej wymiany, a więc wszystko to, co można zaoferować nabywcom do konsumpcji i użytkowania, a co dla nich stanowi określoną wartość. Produktem może być przedmiot, usługa, miejsce, organizacja lub idea (Altkorn, 2004, s. 97). Pojęcie produktu instytucji kultury obciążone jest jednak pewnymi niejasnościami. Może on oznaczać bowiem zbiór dóbr oferowanych przez daną instytucję (w tym znaczeniu rozumiany będzie jako oferta kulturalna) lub konkretne dobro (np. tematyczna wystawa w Muzeum Śląska Cieszyńskiego). Dodatkowo pojęcie produktu podmiotu kultury obejmuje dobra rzeczowe, usługi lub kombinację tych elementów. Rzeczowe produkty to dobra materialne zaspokajające potrzeby konsumentów. Przykładowo galerie sztuki sprzedają takie produkty jak obrazy i rzeźby, antyki czy biżuteria artystyczna. Usługi natomiast to dobra niematerialne, niemające cech fizycznych. Taki charakter ma spektakl teatralny czy lekcja gry na skrzypcach organizowana w domu kultury. Z produktami podmiotów kultury mającymi cechy usług mogą wiązać się również rozmaite dobra materialne, np. posiłki i napoje serwowane w teatralnej kawiarni czy też pamiątki oferowane w muzeum. Biorąc pod uwagę fakt, że znaczna część produktów podmiotów kultury ma cztery wspólne cechy, które wyróżniają przedsiębiorstwa usługowe - mianowicie: niematerialność, nietrwałość, jednoczesność procesu ich świadczenia i konsumpcji oraz niejednolitość (czyli trudność ich wystandaryzowania) — w niniejszym artykule przyjmuje się węższy zakres pojęcia produktu instytucji kultury. Będą to konkretne usługi podmiotów kultury lub pakiet wzajemnie powiązanych, spójnych i komplementarnych usług zaspokajających potrzeby odbiorców.

Produkt jest kluczowym (centralnym) instrumentem marketingu kreującym wartość dla odbiorcy oferty kulturalnej. Dlatego też decydentom odpowiedzialnym za kształtowanie polityki kulturalnej w regionach transgranicznych już na etapie opracowywania produktu powinna towarzyszyć myśl o tym, w jaki sposób za pomocą tego instrumentu nawiązać i wzmacniać relację łączącą instytucję kultury z klientem. Chodzi zatem o swoiste ,wbudowanie” w strukturę produktu elementów służących rozwojowi relacji. Praktyczna realizacja tej idei na transgranicznym rynku nie jest jednak łatwa. Należy bowiem pamiętać że mamy tutaj odbiorców z dwóch różnych państw, posługujących się innym językiem, funkcjonujących w różnych systemach ekonomiczno-prawnych czy wychowanych w innych kulturach. Dodatkowo należy zaznaczyć, że zapisy zawarte w misjach większości samorządowych podmiotów kultury wskazują wyraźnie, iż to mieszkańcy z własnej (narodowej) strony transgranicznego rynku stanowią najważniejszych odbiorców/ potencjalnych odbiorców ich oferty.

Przystępując do projektowania produktu, który będzie przedmiotem wymiany na transgranicznym rynku, według Theodore’a Levitta należy skupić się na trzech głównych poziomach, takich jak: 
- rdzeń produktu, czyli korzyść podstawowa, jakiej oczekuje odbiorca oferty kulturalnej (np. w odniesieniu do spektaklu teatralnego będzie to wzbogacenie własnej wiedzy, ekscytacja, katharsis). Możliwości indywidualizacji oferty kulturalnej na tym poziomie są ograniczone, co nie sprzyja kształtowaniu relacji na transgranicznym rynku;

- produkt rzeczywisty, czyli faktycznie oferowane dzieło, którego cechy materialne i/lub niematerialne zaspokajają potrzebę odbiorcy oferty kulturalnej. W przypadku spektaklu teatralnego na produkt rzeczywisty składać się będzie np. konkretny tytuł sztuki, nazwisko reżysera, obsada aktorska, scenografia, język sztuki (polski lub czeski). Na tym poziomie istnieją już możliwości indywidualizowania produktu, co nie oznacza oczywiście tworzenia zupełnie nowego produktu, który powstał pod dyktando klienta, pozwala natomiast na dokonanie przez odbiorcę wyboru kombinacji spośród standardowych elementów składających się na usługę podmiotu kultury. Przykładowo klient może zdecydować się na konkretny dzień, w którym chce uczestniczyć w spektaklu, wybrać miejsce na widowni (w loży, na balkonie czy w pierwszym rzędzie głównej sali);

— produkt poszerzony - uzupełniony jest o dodatkowe elementy, dodatkową wartość, która najczęściej przybiera formę usługi wzbogacającej produkt rzeczywisty i wyróżnia produkt na tle oferty kulturalnej konkurentów. W odniesieniu do instytucji kultury takiej jak teatr może to być np. możliwość spotkania się po spektaklu z występującymi aktorami, zapisania się do klubu sympatyka teatru, uzyskania autografu znanego artysty czy reżysera sztuki. Odbiorca oferty kulturalnej sam decyduje, które składowe produktu poszerzonego są dla niego ważne, co buduje u odbiorcy poczucie prawdziwej wspólnoty i współuczestnictwa. Instytucja kultury uwiarygodnia w ten sposób jakość swojej oferty, a odbiorca nabiera do niej zaufania, które stanowi niezwykle cenną wartość w procesie kształtowania długotrwałych relacji (w szczególności na etapie wzmacniania więzi) (Levitt, 1980, s. 83-91).

W odniesieniu do transgranicznego rynku usług kultury Śląska Cieszyńskiego istotne jest to, że produkt poddany zostaje ocenie odbiorców zlokalizowanych zarówno po polskiej, jak i czeskiej stronie granicy. Wcześniej jednak spotyka się on z opinią pracowników, menedżerów czy członków rad programowych odpowiedzialnych za kształtowanie struktury produktu, którzy próbują pomóc w skonfigurowaniu oferty kulturalnej w taki sposób, by była ona dla potencjalnego polskiego i czeskiego odbiorcy źródłem możliwie największej wartości. Opinie te dostarczają osobom zarządzającym podmiotami kultury cennych informacji, wskazówek, które mogą mieć wpływ na ostateczny kształt oferty kulturalnej dedykowanej klientom. Oferta ta składać się będzie nie tylko z produktów dedykowanych mieszkańcom (odbiorcom) jednej strony granicy (w tym przypadku można mówić o produktach kultury państw graniczących ze sobą), lecz także transgranicznych produktów kultury, które są źródłem wartości dla mieszkańców obu stron transgranicznego rynku. Termin transgraniczny produkt kultury należy rozumieć zatem jako formę 170 skonkretyzowanej oferty rynkowej zawierającej wspólne elementy składowe 
produktów instytucji kultury państw graniczących ze sobą, objęte wspólną koncepcją (ideą), dystrybucją, komunikacją marketingową oraz ceną.

W tym miejscu należy również podkreślić, że produkty podmiotów kultury występują w postaci prostej (np. pojedyncze wypożyczenie książki w bibliotece miejskiej, koncert muzyki sakralnej organizowany w lokalnym kościele) lub złożonej (np. trzydniowy festiwal filmowy, który obejmuje seanse kinowe, seanse plenerowe, spotkania $\mathrm{z}$ reżyserami, aktorami).

W przypadku TPK, czyli produktu, który powstał na bazie kultury oddziałującej na dwie strony podzielonego granicą terytorium, mamy do czynienia w większości z produktami złożonymi. Głównym założeniem powstania złożonego produktu transgranicznego będzie skorelowanie wielu produktów prostych występujących zarówno na obszarze Polski, jak i Republiki Czeskiej. Dobrymi przykładami takich produktów mogą być: Przegląd Filmowy „Kino na granicy”, Międzynarodowy Festiwal Teatralny „Bez Granic” czy Święto Trzech Braci wszystkie te wydarzenia ulokowane są zarówno po polskiej, jak i czeskiej stronie podzielonego granicą miasta Cieszyn - Czeski Cieszyn. Należy jednak pamiętać, że warunkiem istnienia TPK nie jest jego fizyczne ulokowanie po dwóch stronach granicy państwowej. Na transgranicznym rynku Śląska Cieszyńskiego mamy bowiem produkty z obszaru kultury, które świadczone są wyłącznie po czeskiej lub polskiej stronie miasta i jednocześnie posiadające stałe grono wiernych odbiorców zamieszkałych po drugiej jego stronie (przykładem mogą być spektakle Sceny Polskiej Teatru w Czeskim Cieszynie). Dodatkowo należy zauważyć, że w odniesieniu do TPK nie jest również wymagane fizyczne przemieszczanie się odbiorców $\mathrm{z}$ jednej strony granicy na drugą. W dobie wirtualizacji konsumpcji możliwe są bowiem do opracowania TPK, które konsumowane będą w domowym zaciszu (bez konieczności fizycznego przemieszczania się). Przykładem mogą być wirtualne wycieczki po muzeach opracowane w języku polskim oraz czeskim czy transmisje on-line organizowane przez instytucje kultury (np. transmisje koncertów on-line z Teatru w Czeskim Cieszynie dla licznego grona słuchaczy z Polski realizował PZKO w Republice Czeskiej). Nawiązując do wskazanych cech TPK, można stwierdzić, że:

— zazwyczaj jest on złożony, gdyż stanowi zbiór mniejszej lub większej liczby usług oferowanych przez podmioty kultury na obszarze miast (regionów) dzielących wspólną granicę;

- jest różnorodny, ponieważ elementy TPK są często bardzo urozmaicone, niestandardowe, niejednolite, mogą występować w różnych zestawieniach;

— najczęściej tworzony jest we współpracy podmiotów kultury z zaangażowaniem jednostek samorządu terytorialnego sąsiadujących ze sobą obszarów (miast, stowarzyszeń tworzących euroregion, województw);

- bazuje na potencjale kulturowym obszaru transgranicznego (z Polski i Czech) połączonym w jedną całość, często objętym wspólną nazwą, ideą, promocją (np. Przegląd Filmowy „Kino na Granicy”);

— zarządzanie nim leży w gestii podmiotów kultury i jednostek samorządu terytorialnego znajdujących się po obu stronach granicy; 
— konsumują go zarówno mieszkańcy podzielonego regionu, jak i odwiedzający obszar transgraniczny turyści;

- środki finansowe na kreowanie TPK $\mathrm{w}$ większości pochodzą z unijnych programów pomocowych (np. INTERREG), jednak utrzymanie rezultatów produktu powinny zapewnić podmioty kultury oraz władze samorządowe go tworzące.

TPK to oferta skierowana na rynek, której weryfikacja dokonywana jest przez odbiorców z polskiej i czeskiej strony granicy, dlatego też w procesie kształtowania TPK konieczne będzie współdziałanie podmiotów różnych szczebli (lokalnego, regionalnego, euroregionalnego czy centralnego) zarówno z polskiej, jak i czeskiej strony transgranicznego rynku.

\section{Modelowe ujęcie współpracy podmiotów Euroregionu Śląsk Cieszyński-Těšínské Slezsko w kreowaniu transgranicznych produktów kulturalnych}

Współpraca w procesie kreowania oferty kulturalnej na transgranicznym rynku usług kultury Śląska Cieszyńskiego jest złożona i wielowymiarowa. Z jednej strony charakteryzuje ją bowiem różnorodność podmiotów współtworzących TPK (złożoność podmiotowa - samorządowe instytucje kultury, organizacje trzeciego sektora czy prywatne podmioty świadczące usługi z obszaru kultury), z drugiej z kolei wielość płaszczyzn, na których występuje (złożoność procesu współpracy). Dlatego też skuteczność współpracy podmiotów zaangażowanych w proces kreowania TPK wymaga odpowiednich rozwiązań prawnych na poziomie centralnym czy euroregionalnym, a także jasno określonych kompetencji oraz zadań poszczególnych podmiotów uczestniczących $\mathrm{w}$ tym procesie. Proponowaną koncepcję współpracy w procesie kreowania TPK na transgranicznym rynku usług kultury Śląska Cieszyńskiego z określeniem zależności i relacji pomiędzy podmiotami zaprezentowano na rysunku 2.

W strukturze zaprezentowanej na rysunku 2 wyróżniono różne grupy podmiotów zaangażowanych w proces kreowania oferty kulturalnej na transgranicznym rynku Śląska Cieszyńskiego po polskiej i czeskiej stronie granicy (regionalne i lokalne podmioty kultury, takie jak: samorządowe instytucje kultury, organizacje trzeciego sektora czy prywatne organizacje kultury; władza lokalna, regionalna i euroregionalna; administracja rządowa) oraz ich kompetencje w tym obszarze. Podmioty te występują na czterech głównych poziomach: lokalnym, regionalnym, euroregionalnym oraz centralnym. Stopień zaangażowania poszczególnych podmiotów w kreowanie TPK jest oczywiście różny i zależy również od przynależności organizacji do strony polskiej lub czeskiej oraz płaszczyzny, na której dany 
podmiot występuje. Jest to związane chociażby z różnym profilem kompetencji podmiotów po stronie polskiej i czeskiej oraz z możliwościami podejmowania decyzji. Nie ulega jednak wątpliwości, że współpraca związana z kreowaniem TPK na transgranicznym rynku realizowana jest głównie na szczeblu lokalnym i regionalnym. Na poziomie euroregionalnym oraz centralnym tworzy się z kolei warunki do podejmowania tej współpracy, których znaczenie jest istotne, ale nie rozstrzygające w procesie kształtowania TPK. Powstające na szczeblu centralnym rozwiązania prawne w sposób generalny regulują warunki współpracy międzynarodowej między Polską a Republiką Czeską oraz zasady funkcjonowania podmiotów sfery kultury, lecz nie mają bezpośredniego wpływu na strukturę TPK. Rozwiązania opracowywane na poziomie euroregionalnym wyznaczają z kolei m.in. obszary strategiczne (np. kultura, edukacja, turystyka), które uzyskać mogą wsparcie finansowe Unii Europejskiej za pośrednictwem euroregionu (np. z Funduszu Mikroprojektów) (Studzieniecki, 2005; Studzieniecki, Soares, 2017; Tătar et al., 2020).

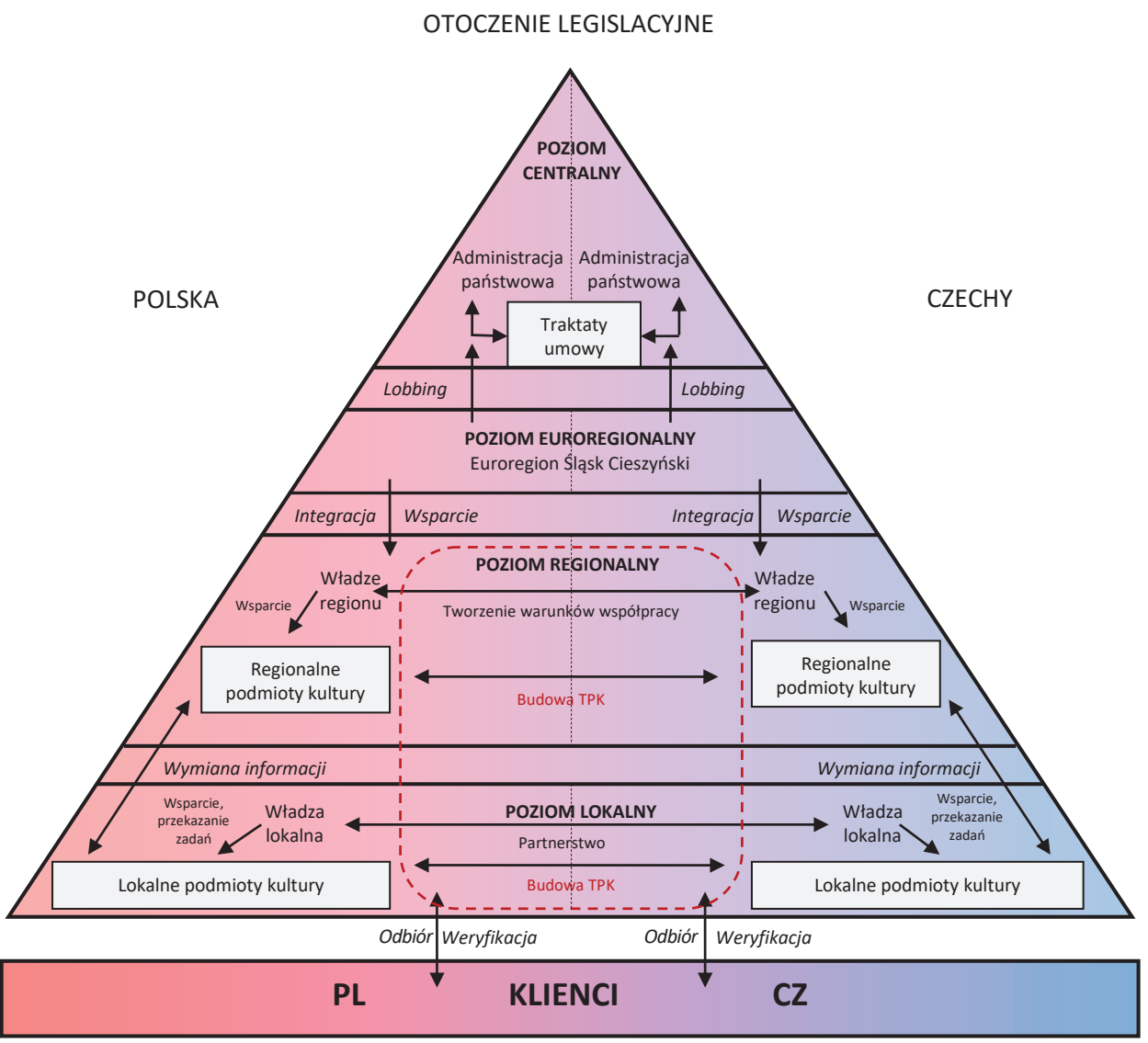

Rys. 2. Schemat modelu współpracy podmiotów w kreowaniu TPK na transgranicznym rynku usług kultury Śląska Cieszyńskiego

Źródło: opracowanie własne na podstawie: Gardzińska 2015, s. 209; Prokkola, Zimmerbauer, Jakola, 2015. 
Na szczeblu najniższym (lokalnym) współpraca samorządów w ramach partnerstwa na polsko-czeskim transgranicznym rynku usług kultury dotyczyć może: - opracowywania wspólnych polsko-czeskich dokumentów strategicznych dotyczących sfery kultury (np. Program dla kultury Cieszyna i Czeskiego Cieszyna); - organizowania wspólnych wydarzeń z obszaru kultury (np. Święto Trzech Braci czy Przegląd Filmowy „Kino na Granicy” w Cieszynie i Czeskim Cieszynie);

- wymiany doświadczeń i dobrych praktyk z obszaru funkcjonowania instytucji kultury (np. organizowane w Cieszynie i Czeskim Cieszynie giełd partnerstw w obszarze kultury czy transgranicznej konferencji naukowej „Współczesne problemy zarządzania i marketingu w instytucjach kultury");

- wspólnych inwestycji infrastrukturalnych (w tym inwestycji w poszczególne elementy transgenicznej oferty kulturalnej, np. Open Air Muzeum czy Ogród Dwóch Brzegów w Cieszynie i Czeskim Cieszynie);

— wspólnej promocji oferty kulturalnej (np. wspólny kalendarz imprez, wspólne materiały promocyjne instytucji kultury opracowywane w języku polskim oraz czeskim).

Kluczowym działaniem na szczeblu lokalnym w kreowaniu TPK na transgranicznym rynku jest zawieranie partnerstw pomiędzy jednostkami samorządu terytorialnego (gminy, miasta, powiaty), w których jednym z obszarów współpracy jest kultura (Stverkova et al., 2018; Sucháček et al., 2018).

Oficjalne porozumienia pomiędzy lokalnymi samorządami są bardzo wyraźnym sygnałem dla różnych podmiotów kultury, wskazującym, że współpraca transgraniczna jest pożądana i wręcz oczekiwana. Innymi słowy, stanowi to punkt wyjścia do nawiązywania współpracy przez podmioty kultury, w tym w szczególności samorządowe instytucje kultury. Jest to jednocześnie istotna forma współdziałania, biorąc pod uwagę fakt, że przy kształtowaniu TPK nie obowiązuje kryterium delimitacji produktu (granicy państwowej, administracyjnej). Samorządy lokalne na pograniczu polsko-czeskim chcące kreować TPK powinny dążyć zatem do opracowania wspólnego dokumentu programowego, w którym wskazany zostanie m.in. kierunek rozwoju transgranicznego rynku usług kultury oraz instrumenty, przy pomocy których ten rynek będzie rozwijany. Przykładowo w Cieszynie i Czeskim Cieszynie dokumentem takim jest opracowany w 2018 roku „Program dla kultury Cieszyna i Czeskiego Cieszyna” lub dokument „Strategia współpracy transgranicznej Cieszyna i Czeskiego Cieszyna w kontekście rozwoju Euroregionu Śląsk Cieszyński" - opracowany w 2019 roku4. Oba dokumenty ukierunkowane są na działania oraz inwestycje obu miast mające na celu rozwój TPK, tym samym przyczyniają się do rozwoju transgranicznego rynku usług kultury Śląska Cieszyńskiego. Z dokumentów tych wynika m.in., że bardzo ważną rolę w procesie kształtowania TPK obok samorządowych instytucji kultury odgrywają lokalne organizacje tzw. trzeciego sektora. Organizacje te bardzo często podejmują się realizacji polsko-czeskich projektów z obszaru kultury finansowanych m.in. z Funduszu Mikroprojektów za pośrednictwem Euroregionu Śląsk

${ }^{4}$ Autor artykułu jest współautorem obu dokumentów. 
Cieszyński-Těšínské Slezsko, które znacząco wzbogacają transgraniczną ofertę kulturalną.

Skuteczność działań podejmowanych w procesie kreowania TPK na poziomie lokalnym transgranicznego rynku usług kultury jest uzależniona również od zakresu współpracy pomiędzy lokalnymi i regionalnymi podmiotami kultury zarówno z polskiej, jak i czeskiej strony. Współpraca taka powinna odnosić się przede wszystkim do wymiany informacji o ofercie kulturalnej, wydarzeniach z obszaru kultury organizowanych w mieście czy regionie, zarówno po polskiej, jak i czeskiej stronie transgranicznego rynku. Kooperacja lokalnych i regionalnych podmiotów kultury z Polski oraz Czech (np. w trakcie regularnych spotkań miejskich oraz powiatowych pracowników wydziałów kultury, instytucji kultury oraz ich odpowiedników po stronie czeskiej) umożliwia prowadzenie wspólnego kalendarza wydarzeń kulturalnych w taki sposób, by oferty różnych podmiotów kultury były względem siebie komplementarne, a terminy poszczególnych wydarzeń z obszaru kultury nie nakładały się na siebie.

Warunki współpracy polsko-czeskiej (w tym również w obszarze kultury) na szczeblu regionalnym reguluje „Porozumienie o współpracy pomiędzy Województwem Śląskim (Rzeczpospolita Polska) i Krajem Morawsko-Śląskim (Republika Czeska)" podpisane dnia 21 listopada 2001 roku w Ostrawie. Strony w podpisanym porozumieniu jako jednostki samorządu terytorialnego przyjęły zgodnie ze swoimi właściwościami, że współpraca dotyczyć będzie w szczególności następujących dziedzin: gospodarki, ochrony środowiska, transportu i komunikacji (transport drogowy, kolejowy i wodny), restrukturyzacji przemysłu ciężkiego, administracji samorządowej, nauki i oświaty, turystyki, sportu i rekreacji, a także kultury, oraz obejmować będzie wspólne działania dotyczące wymienionych dziedzin. Regionalne polskie oraz czeskie władze w procesie kreowania TPK pełnią funkcję organów wspierających i wspomagających. Współpraca (także z władzami lokalnymi) jest niezbędna chociażby przy tworzeniu np. transgranicznych rozwiązań komunikacyjnych, które zwiększają dostępność do oferty kulturalnej, czy promowaniu idei ,jednego biletu” do wybranych polskich i czeskich instytucji kultury. Udział polskich oraz czeskich władz regionu w kreowaniu TPK polegać może w szczególności na:

— tworzeniu warunków do podejmowania współpracy transgranicznej między podmiotami kultury;

— inicjowaniu inwestycji w infrastrukturę z obszaru kultury;

— dysponowaniu funduszami unijnymi;

- nadzorze prawnym i administracyjnym;

- opracowywaniu, koordynacji i realizacji strategii i programów rozwoju oferty kulturalnej na szczeblu regionalnym.

Podmioty kultury funkcjonujące na płaszczyźnie regionalnej odgrywają istotną rolę w procesie kreowania TPK. Przykładem takiej regionalnej instytucji na pograniczu polsko-czeskim może być Zamek Cieszyn (samorządowa instytucja kultury prowadzona jako wspólna instytucja kultury dwóch organizatorów, tj. miasta i województwa), który jest m.in. inicjatorem powstania Śląskiego Klastra Dizajnu. 
Klaster ten łączy innowacyjne firmy, naukowców i projektantów. Spoiwem jest design jako narzędzie, które pomaga wyróżnić się na rynku, poprawić zarządzanie czy obniżyć koszty. Podstawą funkcjonowania klastrów jest założenie, że nawet podmioty, które na co dzień walczą o ten sam rynek, mogą współdziałać, szczególnie gdy założone cele łatwiej można osiągnąć, współpracując niż konkurując. W Zamku Cieszyn uwierzono, że ogniwem łączącym różne dyscypliny wiedzy i gospodarki na pograniczu polsko-czeskim może być design, a Śląski Klaster Dizajnu może stać się pomostem ułatwiającym współpracę́. Dobry przykład płynący ze szczebla regionalnego z całą pewnością przyczynia się do wytwarzania pozytywnego klimatu współpracy na poziomie lokalnym.

Na płaszczyźnie euroregionalnej główną rolę w kreowaniu TPK odgrywa Euroregion Śląsk Cieszyński-Těšínské Slezsko, którego zadaniem jest przede wszystkim integracja polskich oraz czeskich samorządów lokalnych, wspieranie współpracy partnerskiej między nimi oraz kojarzenie ze sobą potencjalnych partnerów transgranicznych inicjatyw kulturalnych. Dzięki ponadlokalnemu i transgranicznemu charakterowi euroregion spełnia funkcje koordynacyjne dla pewnego zakresu działan podejmowanych $\mathrm{w}$ jednostkach terytorialnych, które są jego członkami. Uwarunkowaniem rozwoju współpracy w procesie kształtowania transgranicznej oferty kulturalnej na polsko-czeskim rynku jest położenie w obszarze jego działania. Dzięki temu można wykorzystać środki finansowe programów europejskiej współpracy terytorialnej INTERREG, które nie są dane innym regionom. Podstawą funkcjonowania euroregionu jest przede wszystkim umowa zawierana między władzami regionalnymi a lokalnymi. Współpraca euroregionalna ma na celu podejmowanie i harmonizowanie różnorodnych działań zarówno w obszarze kultury, jak i nauki, oświaty czy gospodarki. Co bardzo ważne, realizowane we współpracy polsko-czeskiej działania powinny być korzystne dla obydwu stron, a także służyć pogłębianiu wzajemnych relacji między instytucjami, podmiotami gospodarczymi oraz mieszkańcami lokalnych społeczności (Wieczorek, Ganczar, red., 2016, s. 17). Atutem Euroregionu Śląsk Cieszyński-Těšínské Slezsko jest z pewnością jego większa elastyczność w zakresie podejmowanych działań. Szeroki wachlarz działań statutowych umożliwia m.in. realizację wielu transgranicznych inicjatyw, w tym bardzo często z obszaru kultury. Można z całą pewnością stwierdzić, że jednostka ta ma pod pewnymi względami „wygodniejszą" pozycję aniżeli samorządy terytorialne, które muszą realizować pewien określony pakiet zadań własnych.

Omawiając płaszczyznę współpracy na poziomie euroregionalnym, należy również pamiętać o alternatywie dla euroregionów, jaką są Europejskie Ugrupowania Współpracy Terytorialnej (EUWT) (Böhm, 2014, s. 9). Obowiązujące regulacje prawne pozwalają bowiem na tworzenie na pograniczu polsko-czeskim ugrupowań wyposażonych w osobowość prawną, zajmujących się współpracą obszarów przygranicznych. W Polsce 25 lutego 2013 roku decyzją Ministra Spraw Zagranicznych RP nr 1/2013 zarejestrowano EUWT Tritia ${ }^{6}$, działające na

${ }^{5}$ Więcej na ten temat w: Wróblewski, 2016.

${ }^{6}$ Nazwa Tritia wskazuje na trzech partnerów, nawiązuje do nazewnictwa historycznego i geograficznego regionów europejskich, jest określeniem nowym, nie zapożyczonym. 
terenie Polski, Czech i Słowacji, którego członkami są władze regionalne. Obszar aktywności działań EUWT Tritia obejmuje wspólne terytorium, jakim jest Region Morawsko-Śląski w Czechach, Województwo Śląskie w Polsce oraz Samorządowy Kraj Żyliński na Słowacji. EUWT Tritia wykonuje zadania mające na celu identyfikację, promowanie i realizację programów, projektów, wspólnych inicjatyw współpracy terytorialnej w czterech głównych obszarach: transport, gospodarka, ruch turystyczny, energetyka ukierunkowana na odnawialne źródła energii, i w pięciu obszarach dodatkowych, takich jak: kultura, ochrona środowiska, kapitał ludzki, edukacja i współpraca szkół wyższych, szkolenia, w tym ścisła współpraca z uczelniami, współpraca z instytucjami publicznymi, a także realizacja wymiany doświadczeń i staży międzynarodowych oraz sport (http://www.egtctritia.eu/pl/ [dostęp: 20.01.2020]).

Relacje warunkujące współpracę na poziomie lokalnym, regionalnym czy euroregionalnym zachodzą również na płaszczyźnie centralnej. Powiązania transgraniczne na szczeblu centralnym (międzyrządowym, międzypaństwowym) polegają zasadniczo na zawieraniu odpowiednich traktatów, umów międzynarodowych i innych aktów prawa międzynarodowego, które działają jako podstawy dalszych regulacji na niższych szczeblach, ale również jako stymulatory podejmowania inicjatyw transgranicznych przez społeczności lokalne i regionalne (Prokkola, 2019; Vulevic et al., 2020). Umowy dwustronne regulujące wzajemne relacje zawarte między rządem Polski a rządem Republiki Czeskiej (np. Umowa między Rzecząpospolitą Polską a Republiką Czeską o współpracy w zwalczaniu przestępczości, ochronie porządku publicznego oraz o współpracy na terenach przygranicznych) oraz inne obowiązujące normy i akty prawne tworzą zatem otoczenie legislacyjne dla współpracy podmiotów kultury w zakresie kreowania TPK. Władze centralne w procesie tym pełnią dodatkowo funkcję doradczo-konsultacyjną, np. nadzorując zgodność podejmowanych przez podmioty kultury działań transgranicznych $\mathrm{z}$ ustawodawstwem wewnętrznym i interesami kraju czy promując regiony transgraniczne na forum europejskim.

\section{Zakończenie}

Aktualna sytuacja geopolityczna Polski oraz Republiki Czeskiej tworzy dobry klimat dla działań i skuteczności podmiotów działających na transgranicznym rynku Śląska Cieszyńskiego mających na celu kreowanie TPK. Z jednej strony wejście w struktury unijne, a następnie do strefy Schengen, zdecydowanie umożliwia korzystanie z oferty kulturalnej przez odbiorców zlokalizowanych po dwóch stronach polsko-czeskiej granicy. Z drugiej - Unia Europejska poprzez poziom środków desygnowanych na obszary przygraniczne ułatwia funkcjonowanie podmiotów kultury funkcjonujących na transgranicznym rynku. $Z$ przeprowadzonych przez autora w latach 2013-2019 badań realizowanych na pograniczu polsko- 
-czeskim ${ }^{7}$ wynika, że w proces kreowania TPK oprócz lokalnych i regionalnych podmiotów kultury Śląska Cieszyńskiego zaangażowany jest przede wszystkim Euroregion Śląsk Cieszyński-Těš́nské Slezsko. Aktywność euroregionu nie ogranicza się jednak jedynie do pośredniczenia $\mathrm{w}$ finansowaniu projektów z obszaru kultury, czy weryfikacji efektów dofinansowanych projektów. W ramach działań własnych prowadzi on również m.in. stały monitoring potrzeb kulturalnych mieszkańców po obu stronach granicy, a także wspiera działalność badawczo-naukową np. w ramach powołanego Euroinstytutu Polsko-Czesko-Słowackiego.

Reasumując, w opinii autora działania Euroregionu Śląsk Cieszyński-Těšínské Slezsko mają kluczowe znaczenie dla dalszego rozwoju TPK. Są one bowiem skoncentrowane na inicjowaniu i wspieraniu transgranicznych projektów kulturalnych zmierzających do uznawania za cenną w życiu społecznym różnorodność, a także działaniach sprzyjających nie tylko rozwojowi tolerancji wobec występujących w lokalnej społeczności zróżnicowań kulturowych, ale również akceptacji tych zróżnicowań, uznanie ich za wartość (Klatt, 2004; Prokkola, 2011; Kurowska-Pysz, Ulrich, 2019).

Ważna w tych działaniach jest zarówno znajomość specyfiki i struktury TPK, jak i zaprezentowany w artykule schemat modelu współpracy podmiotów w kreowaniu TPK na transgranicznym rynku usług kultury Śląska Cieszyńskiego.

\section{Bibliografia}

Altkorn J., 2004: Marketing w turystyce. Warszawa: Wydawnictwo Naukowe PWN.

Banaszak G., Kmita J., 1994: Społeczno-regulacyjna teoria kultury. Warszawa: Instytut Kultury.

Böhm H., 2014: A Comparison of Governance forms For Cross-border Co-operation Within the EU. "Journal of Cross-border Studies", Vol. 9, s. 36-50.

Conrad J., 1971: Człowiek, rasa, kultura. Warszawa: Wydawnictwo Naukowe PWN. Dobrowolski K., 1966: Studia nad życiem spolecznym i kultura. Wrocław: Ossolineum. Fleischer M., 2002: Teoria kultury i komunikacji. Systemowe i ewolucyjne podstawy. Wrocław: Dolnośląska Szkoła Wyższa Edukacji Towarzystwa Wiedzy Powszechnej. Fundusz Mikroprojektów Programu Operacyjnego Współpracy Transgranicznej Republika Czeska-Rzeczpospolita Polska 2007—2013 w Euroregionie Śląsk Cieszyński, Cieszyn 2015.

Gardzińska A., 2015: Transgraniczny produkt turystyczny. Szczecin: Wydawnictwo Naukowe Uniwersytetu Szczecińskiego.

7 Autor w latach 2013-2019 był kierownikiem, koordynatorem lub członkiem zespołu badawczego następujących polsko-czeskich projektów realizowanych we współpracy z Euroregionem Śląsk Cieszyński oraz Euroregionem Beskidy: „Kulturalna inicjatywa edukacyjno-naukowa RAZEM DLA POGRANICZA” (2013-2014); „,Rozwój współpracy naukowo-dydaktycznej uczelni wyższych w Euroregionie Beskidy” (2014); „Program dla Kultury Cieszyna i Czeskiego Cieszyna” (2017-2018); „,Polsko-czeska współpraca akademicka na rzecz doskonalenia jakości transgranicznych badań naukowych” (2018-2019); „Český Těšín/Cieszyn INEurope” (2018-2019). 
Greta M., 2000: Integracja sasiedzka. Znaczenie euroregionów. W: Integracja Europejska. Red. A. Marszałek. Łódź: Wydawnictwo Uniwersytetu Łódzkiego, s. 457474.

Kasperek A., red., 2014: Euroregion Śląsk Cieszyński-Těšinské Slezsko Współpraca transgraniczna $i$ międzyregionalna prowadzona $w$ obszarze trójstyku polsko-czesko-słowackiego. „TRANSCARPATHICA”, Prace EuroInstytutu Polsko-Czesko-Słowackiego. Cieszyn-Katowice: Polska Akademia Nauk Oddział w Katowicach, Stowarzyszenie Rozwoju i Współpracy Regionalnej „Olza”.

Kasperek B., red., 2014: Euroregiony pogranicza polsko-czeskiego - Euroregiony polsko-českého pohraničí. Cieszyn: Stowarzyszenie Rozwoju i Współpracy Regionalnej „Olza”.

Klatt M., 2004: Regional Cross-Border Cooperation - Ideological vs. Practical Approach. W: Narva and the Baltic Sea Region. Ed. K. Brüggemann. Narva: Tartu University Narva College, s. 391-400.

Klatt M., 2017: The Danish-German Border Region: Caught Between Systemic Differences and Re-Bordering. "Eurasia Border Review", Vol. 8(1), s. 15-30.

Kłoskowska A., 1980: Kultura masowa. Krytyka i obrona. Warszawa: Wydawnictwo Naukowe PWN.

Kmita J., 1982: O kulturze symbolicznej. Warszawa: Centralny Ośrodek Metodyki Upowszechniania Kultury.

Kmita J., 1994: Społeczno-regulacyjna teoria kultury. Warszawa: Instytut Kultury.

Kroeber A., Parsons T., 1958: The Concept of Culture and of Social Systems. "American Sociological Review", Vol. 23(5), s. 582-583.

Kurowska-Pysz J., Ulrich P., 2019: Polish-German Cooperation in the Field of Cultural Heritage: The Case of the European Park Association of Lusatia. "Cultural Management: Science and Education", Vol. 3(2), s. 123-143.

Levitt T., 1980: Marketing Success Through Differentiation - Of Anything. "Harvard Business Review", Vol. 58(1), s. 83-91.

Malendowski W., Szczepaniak M., 2000: Rola euroregionów w procesie integracji europejskiej. W: Euroregiony - mosty do Europy bez granic. Red. W. Malendowski, M. Szczepaniak. Warszawa: Dom Wydawniczy Elipsa, s. 9-15.

Mierosławska A., 1999: Euroregiony na granicach Polski. Warszawa: Instytut Ekonomiki Rolnictwa i Gospodarki Żywnościowej.

Niestrój R., 1998: Zarządzanie marketingiem. Aspekty strategiczne. Warszawa-Kraków: Wydawnictwo Naukowe PWN.

Olbrycht J., 2014: Przez przeszłość w stronę przyszłości. W: Euroregion Ślask Cieszyński-Těšinské Slezsko Wspótpraca transgraniczna i międzyregionalna prowadzona w obszarze trójstyku polsko-czesko-stowackiego. Red. A. Kasperek. „TRANSCARPATHICA”, Prace EuroInstytutu Polsko-Czesko-Słowackiego. Cieszyn-Katowice: Polska Akademia Nauk Oddział w Katowicach, Stowarzyszenie Rozwoju i Współpracy Regionalnej „Olza”, s. 11-12.

Pietraszko S., red., 1982: Przedmiot i funkcje teorii kultury. Wrocław: Wydawnictwo Uniwersytetu Wrocławskiego.

Prokkola E.K., 2011: Cross-Border Regionalization, the INTERREG III: A Initiative, and Local Cooperation at the Finnish-Swedish Border. "Environment and Planning", Vol. 43(5), s. 1190-1208.

Prokkola E.K., 2019: Border-Regional Resilience in EU Internal and External Border Areas in Finland. "European Planning Studies", Vol. 27(8), s. 1587-1606. 
Prokkola E.K., Zimmerbauer K., Jakola F., 2015: Performance of Regional Identity in the Implementation of European Cross-Border Initiatives. "European Urban and Regional Studies", Vol. 22(1), s. 104-117.

Studzieniecki T., 2005: Euroregions - New Potential Destinations. “Tourism Review", Vol. 60(4), s. 26-32.

Studzieniecki T., Soares J.R.R., 2017: Interregional Tourism Cooperation: A Europe Case Study. "Holos", Vol. 33(4), s. 135-158.

Stverkova H., Pohludka M., Kurowska-Pysz J., Szczepańska-Woszczyna K., 2018: Cross-Border Enterprepreneurship in Euroregion Beskydy. "Polish Journal of Management Studies", Vol. 18(2), s. 324-337.

Sucháček J., Walancik M., Wróblewski Ł., Urminský J., Drastichová M., Šotkovski I., 2018: Management of Municipal Development of Euroregion Beskydy in Poland and Czechia. "Polish Journal of Management Studies", Vol. 18(1), s. 365-378.

Tătar C.F., Studzieniecki T., Czimre K., Penzes J., 2020: Marketing Awareness of Cross-Border Destination - The Case Study of Bihor - hajdu/bihar Euroregion. "GeoJournal of Tourism and Geosites", Vol. 28(1), s. 95-103.

Toczyski W., Sartorius W., Zaucha J., red., 1997: Międzynarodowa wspótpraca regionów - wybór ekspertyz. Warszawa: Wydawnictwo Przedświt, s. 107-108.

Vulevic A., Castanho R.A., Naranjo Gómez J.M., Loures L., Cabezas J., Fernández-Pozo L., Martín Gallardo J., 2020: Accessibility Dynamics and Regional Cross-Border Cooperation (CBC) Perspectives in the Portuguese - Spanish Borderland. "Sustainability", Vol. 12(5): 1978 [dostęp: 23.11.2020].

Werpachowski L., 2014: Regionalna wspótpraca transgraniczna na Śląsku Cieszyńskim Doświadczenia i perspektywy. W: Euroregion Śląsk Cieszyński-Těšinské Slezsko Wspólpraca transgraniczna $i$ międzyregionalna prowadzona $w$ obszarze trójstyku polsko-czesko-stowackiego. Red. A. Kasperek. „TRANSCARPATHICA”, Prace EuroInstytutu Polsko-Czesko-Słowackiego. Cieszyn-Katowice: Polska Akademia Nauk Oddział w Katowicach, Stowarzyszenie Rozwoju i Współpracy Regionalnej „Olza”, s. 15-25.

Wieczorek I.M., Ganczar M., red., 2016: Wybrane aspekty wspótpracy transgranicznej polskich samorzadów w kontekście przemian prawa Unii Europejskiej. Łódź: Wydawnictwo Naukowe Doctrina.

Wróblewski Ł., 2016: Marketing strategiczny w sektorze kultury Euroregionu Ślask Cieszyński. Warszawa: CeDeWu.

Wróblewski Ł., 2018: Structure and Conditions for the Functioning of the Polish-Czech Cross-Border Market of Cultural Service. "Ekonomski vjesnik", Vol. 31(2), s. 371384.

Wróblewski Ł., Dziadzia B., Dacko-Pikiewicz Z., 2018: Sustainable Management of the Offer of Cultural Institutions in the Cross-Border Market for Cultural Services Barriers and Conditions. "Sustainability", Vol. 10(9), s. 1-30.

Wróblewski Ł., Kasperek A., 2019: Euroregion as an Entity Stimulating the Sustainable Development of the Cross-Border Market for Cultural Services in a City Divided by a Border. "Sustainability", Vol. 11(8): 2232 [dostęp: 23.11.2020]. 